\title{
Digitalization of North Sumatera Malay Ritual Music Using Cubase 5 Software
}

\author{
Wiflihani $^{1}$, Pita HD Silitonga ${ }^{2}$, Herna Hirza $^{3}$ \\ ${ }^{1,2,3}$ Music Education Study Program, Sendratasik Department, Languages and Arts Faculty, Universitas Negeri \\ Medan, Indonesia \\ wiflihani@unimed.ac.id
}

\begin{abstract}
The high level of need of dance artists in North Sumatra for digital audio of Malay ritual dance music while the digital material is not publicly available. This triggers researchers to conduct research on the use of this cubase music software as an alternative in the process of packaging the learning material of musical accompaniment of the Gobuk Bedagai Malay ritual dance into digital audio. The method used in this study is an experimental approach to the process of packaging the learning material of musical accompaniment of the Gobuk Bedagai Malay ritual dance into digital audio. The packaging process by recording audio and video ritual dance performances in the coastal areas of North Sumatra Malay. The results of this study indicate that the process of creating digitalization consists of recording, editing, mixing and mastering using cubase.
\end{abstract}

Keywords: Digitization; music; ritual dance; Malay; cubase.

\section{Introduction}

In community of North Sumatra Coastal Malay found various rituals that are used as medical media. This culture is formed as part of belief in ancestral spirits that influence their life processes. Among the rituals are the gobuk dance rituals in community at Tanjung Beringin Serdang Bedagai, the dance rituals of making Ubat in Batubara community, and menghanyut lancang rituals known by Langkat community. These rituals are usually presented in the form of dance accompanied by music. Music is one of the main elements in this medical ritual. Music is used to convey mantras that are sung by bomo (shaman). Along with the times, these rituals have changed the function of the form of rituals into a performance art.

The main objective of this study is to produce new concepts and innovations in the method of packaging music accompaniment to the North Sumatra Malay ritual dance based on the use of digital music software. This thinking is based on the need to adjust to the development of the era that has entered the industrial era 4.0. Where industry 4.0 requires us to work with digital concepts, including in the world of the performing arts.

Literature studies can be seen from several previous studies including: 1) Arfah (2009) research on the function and symbolic meaning of gobuk dance in Tanjung Balai, Asahan, 2) Fernandus (2017) research on gobuk dance in Malay community on the coast of Asahan 3) Hamdani (2019) research on gobuk treatment and Malay art Asahan, 4) Laksono (2018) research on digital development technology in developing compositions and arrangements in music using Cubase software. The results of this research have shown data on the structure of the presentation, organology form of the instrument, symbolic meaning, and game techniques, but have not touched the areas of production and packaging of ritual dance performances, especially in the area of music.

The main problem faced is there is no reference musical accompaniment of ritual dance in the form of digital audio, both in the form of original music and creative music. This becomes an obstacle in the learning process and musical accompaniment of North Sumatra ritual dance. If this condition is allowed to drag on, it is feared that the accompaniment of 
ritual dance music as part of the treasures of North Sumatra traditional musical wealth will be eliminated and even become extinct.

Research on digitization of the accompaniment music of the North Sumatra Malay ritual dance by utilizing this cubase software is a solution. The use of cubase music software can be an alternative approach in the process of packaging the ritual dance accompaniment as a teaching and performance media. Choices of varied and attractive sound banks and complete recording features open up a vast exploration space for the digitalization process of ritual dance accompaniment.

Considering the types of Malay ritual dance in North Sumatra, the initial step of this study focused on the ritual music of Gobuk treatment in the village of Tanjung Beringin, Serdang Bedagai District, to be the object of research.

\section{Research Methods}

The method used in this study is an experimental approach to the process of creating musical accompaniment of Malay Gobuk Bedagai ritual dance accompaniment into digital audio form. The packaging process by recording audio and video ritual dance performances in the coastal areas of the North Sumatra Malay. Completeness needed is a video camera, photo and audio recording tool that is useful for documenting data. The selection of informants is based on the grouping of key informants that includes music artists and Sumatran Malay ritual dance artists. The number of informants is unlimited as long as the data needed is still needed to answer the purpose of this study.

The stages and steps that will be carried out in this study are:

1. The research preparation stage which includes searching for ideas, conducting literature studies, determining research topics, formulating problems and research objectives, determining research locations, and establishing research methods.

2. Data collection stage. Primary data obtained through in-depth interviews and participant observation which aims to collect data followed by focus group discussions.

3. Data analysis stage is done by categorizing and analyzing data then having discussions with experts. Furthermore, formulating the concept and Packing model of the accompaniment music of the Malay Sumut ritual dance digital-based using cubase software.

4. Production stage of digitization of the accompaniment music of the North Sumatra Malay ritual dance using cubase software by doing studio work based on the concepts and models of the results of studies that have been carried out.

5. Summarize the results and research findings stage.

Video-audio recording is needed to record information during the interview process. Through this method, data collected from interviews can be played back repeatedly. This will help to repeat the audio-video interview when needed in the data analysis stage so that it can be sure that no data has been missed and produced accurate data.

The software used to digitize the music of the North Sumatra Malay ritual dance is Cubase, which is a software that is classified as a composer because cubase was created to create, record, combine, and rewrite existing music to become works ready to be enjoyed. Cubase is one of the Digital Audio Workstation software that has the function of storing and processing digital audio signals that have been changed by hardware to convert analog audio 
signals into digital audio signals, known as sound cards (sound cards). Cubase created a software that makes it easy for operators to make changes (editing) on MIDI data, raw audio tracks, and other important data such as lyrics, instrument selection, editing console, and others. The operator can also process some audio data to make it stereo data that has a WAV format and is ready to be distributed to the internet or duplicated using a CD format.

Cubase is a music software product developed by Steinberg Media Technologies $\mathrm{GmbH}$ in Germany. The first version of Cubase only runs on the Atari ST computer and only records via MIDI, released in 1989. In January 2003, Steinberg was acquired by the US Company Pinnacle Systems, where it operated as an independent company before being sold to Yamaha Corporation in December 2004. While cubase used for this study is the Cubase 5 series.

\section{Result and Discussion}

\subsection{Gobuk Ritual Music}

Gobuk is a ritual tradition of medicine that was born and developed in the Malay community on the coast of Bedagai, Serdang Bedagai Regency, North Sumatra. This Bedagai coast is dominated by ethnic Malays. Its geographical position close to the sea makes the majority of people depend on the sea, working as fishermen. So, people here believe that the sea has a big contribution to their lives.

Gobuk dance is believed by Bedagai community as a ritual treatment to cure someone's illness. As coastal fishermen who depend their lives on the sea world, Bedagai community believe that there is a great power possessed by the sea. Therefore there must be a power that protects them in life. So they make friends with the Jin people. Jin or supernatural beings by the Malay community called Puako.

This Puako protection must certainly be returned with a meal or offer at certain times. If the owner forgets to give a Puako dinner, the Puako will leave the illness to a family member, usually a girl. In order for the disease to heal, a feast must be held to persuade Puako.

The meal consisted of music, dances, presentation of offerings, and menghanyut lancang (boat). The music presented is included in the study of ethnic music that is monotonous with repeated rhythm and melody. The instrument consists of a two-face drum, flute, sarune, gong and incantations that hum.

Rituals are intended to treat sick people. According to Aziz (September 2011), in 1895, one of the daughter of Penghulu (village chief) was seriously ill. Various attempts have been made to treat it, but never succeeded. Belief in supernatural forces led villagers to conclude that the girl's illness was a result of the disruption of Puako (sea Jin). So the Penghulu took the initiative to meet Bomo (Shaman) to ask for help. The shaman was ordered to hold a banquet for the sea Jin.

The ritual is designed like a party for Puako (genie). Consisting of music, dance, and led by a shaman. The location of the ritual was arranged like a garden with Coconut as decoration in hopes that Puako would be interested to attend and play in the garden so that he would later treat the girl's illness. Named Gobuk ritual because in this garden 7 pieces of gobuk were arranged where dancers and Puako danced together. Gobuk is a type of jug made from dry soil. 


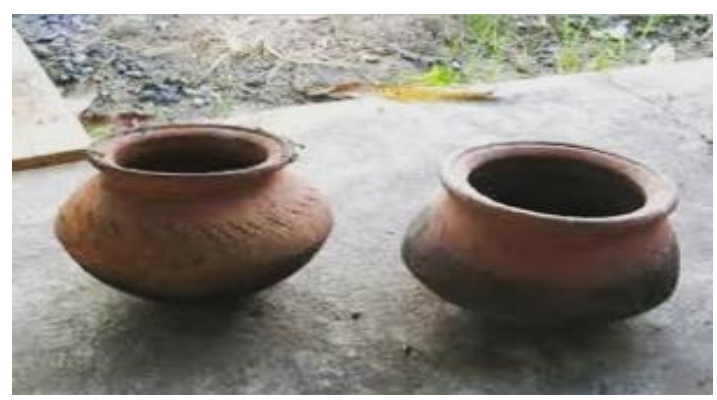

Figure 1. Gobuk (Muhar, 2015)

Gobuk rituals spend all night long. Starting from the preparation of the area, dancing, calling Puako, until the final process of drifting sassy (miniature sampans made from banana stems.
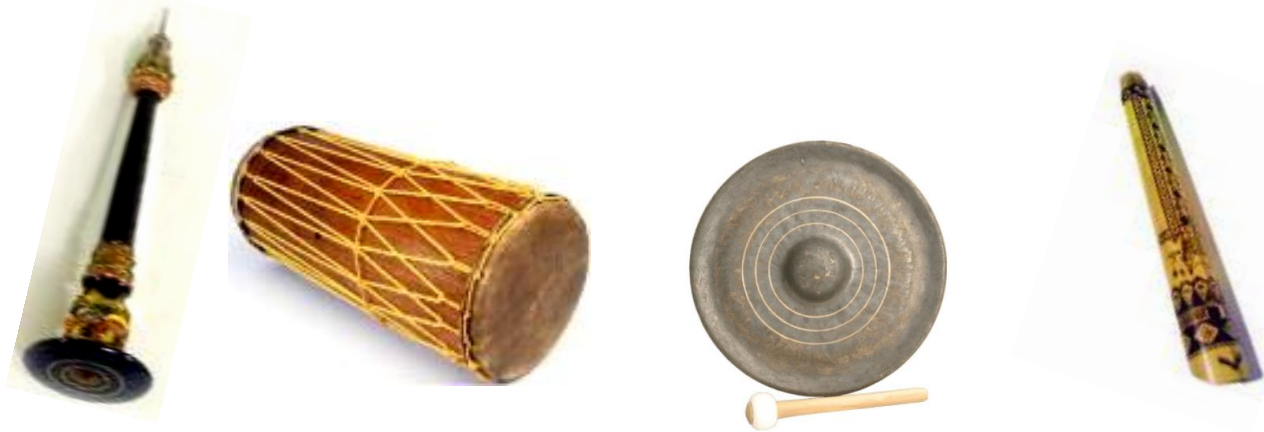

Figure 2. Musical Instruments in Gobuk Ritual

In some areas, the sound produced by certain instruments or instruments is believed to have magical powers. Therefore, such an instrument is used as a means of community custom activities. Likewise with the music that is played in the gobuk dance art. The sounds produced are believed by the local community as a means to summon Puako.

The music in the gobuk ritual consists of 3 major parts. The first part is the opening part, called Hontak Kudo and Senandong, played in a medium tempo. The second part is the core part called magic or magic, played in fast tempo. While the third part is the final or closing part or climax, referred to as porang music, played in a very fast tempo.

Music in Malay Gobuk acts as a major component of the healing process. Music in Malay gobuk is categorized as "Original Music". "Original music is a song played by a shaman or "handler" in healing rituals such as Nobat Diraja (Basarsyah, 2002). There are two main musical components in gobuk, instrument and vocal.

Gobuk musical instruments consist of percussion and melodic music. Then grouped again into membranophone and idiophone classes. Included in the membranophone is the Long Drum. This long drum is made of leather on both sides. Two pieces are always played, the big one is called the "main drum" and the smaller one is called the "children's drum". An average length of 21 inches is made of hard and durable merbau wood. One side is smaller than the other side. Children's drum is made of goat skin and the parent drum is made of buffalo skin. The skin that is located on both sides is tied with a twisted rattan (Basarsyah, 2002). 
While those included in the idiophone group consisted of Canang and Gong. Canang in Malay, both in form and sound, looks like Canang elsewhere because of cross-culture and mutual effect. "For example Canang (small gong) is also in Thailand called "Khong Wong Yai", in Burma and in the kulintang music of Sabah". Whereas Gong, according to Basarsyah (2002) explains this instrument as follows:

In the East Sumatran Malay, a kind of gong with a thick side called tetawak is used to accompany the Ronggeng entertainment dance. In traditional music, accompanying traditional Malay theaters such as Makyong, Mendu, Menora and Wayang Kulit Melayu 2 pieces of gong are used, the mains are pitched $\mathrm{C}$ and the gong is pitched with $\mathrm{G}$.

The instrument that functions as a melody carrier is Serunai or Sarunai. This is categorized as an aero phone class. This instrument does not use a melodic system like Western music ( $s o l$ mi sa si) but is played as a long-high note. High and small (high-pitched) chime tone. Nasuruddin (1989) says that cone-shaped chunks have seven holes above and one below. The player squeezed and released a continuous flutter without stopping to take a breath.

The vocal singing style in Gobuk Melayu is hummed. The humming melody is full of Twisted and Grenek. Rizaldi (2010, 21 August), said that "Cengkok and Grenek are ornamental or ornamental tones as a general feature of Malay music, functioning to beautify the melody played by melodic instruments or singers"

Examples of Cengkok and Grenek:

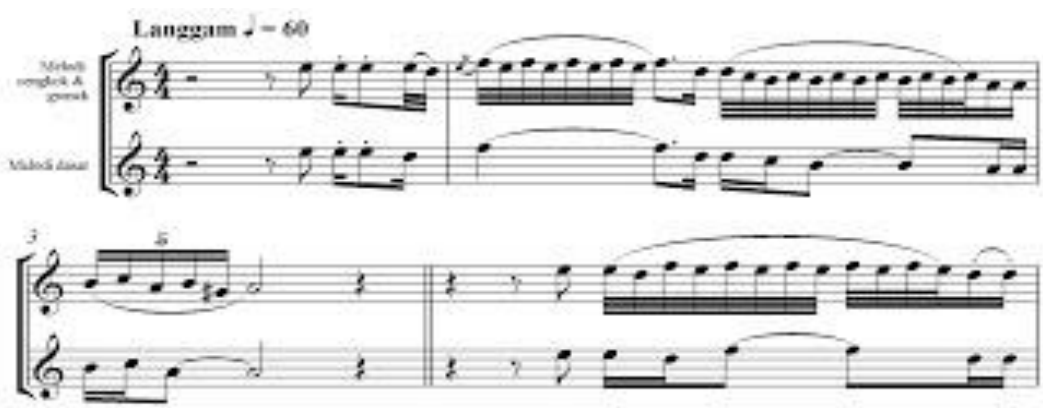

Figure 3. Cengkok and Grenek in western notation (Rizaldi, 2010)

Cengkok adds notation as ornament before heading to the main notation. Whereas grenek sounds like trilling in Western music techniques. For example, in the first beat of bar 2 we can see the grenek shape in a series of melodies that are played with only two 1/32 notes ( $\mathrm{F}$ and $\mathrm{E}$ ) that are repeated up and down continuously. Then, in bar 3 shows an example of the melody in the form of a quintole (with the number 5 on it).

This form of melody is called Cengkok in Malay music. Melody movements are usually step-down with a jumping tone (see notation). In notation it can be seen that tone $\mathrm{B}$ goes down to note $\mathrm{A}$, but before getting note $\mathrm{A}$ it jumps forward to note $\mathrm{C}$ then goes down to $\mathrm{A}$, then goes back to tone B and goes down to Gis tone down again to note a. Cengkok like this movement is mostly found at the end of melody in Malay music.

The text of the gobuk dance song is "Spell". The text of the Spell is written in the form "Pantun". Initially, rhymes are delivered verbally. Rhymes are delivered by singing or singing, so that rhymes cannot be separated from poetry.

There are many traditions in Malay that use rhyme as a calling of enthusiasm. In agrarian societies, rhymes are used to grow rice or other crops as well as catches of hunted 
animals and to take honey bees. Whereas in marine society, rhyme is used to call fish or call the wind. In both maritime and agrarian societies, pantun is also always used as a spell in traditional medicine as well as efforts to expel gnome, mambang, or other spirits (Dahlan, 2015).

Meanwhile, the humter in the Gobuk ritual is the ritual leader or Bomo. "Malay people on the Peninsula often use different names for witches. In Perak and Kelantan, witches are called as handlers while shamans are called belian, while in other Malay areas there are also those who call shamans as bomo (Winstedt, 1993).

\subsection{The Process of Digitalization of Gobuk Bedagai Ritual Music}

In the process of digitalization of gobuk Bedagai ritual music is divided into 3 stages namely recording, editing, mixing and mastering.

Recording stage, starting with adjusting the recording device settings. Besides cubase 5 software, other tools that support the recording process are as follows:

1. Laptop to operate Cubase software 5

2. Soundcard or audio interface

3. Condenser microphone

4. Microphone stand

5. Pop the filter

6. Monitor speaker

7. Headphones

The settings for these recording devices are as shown below:

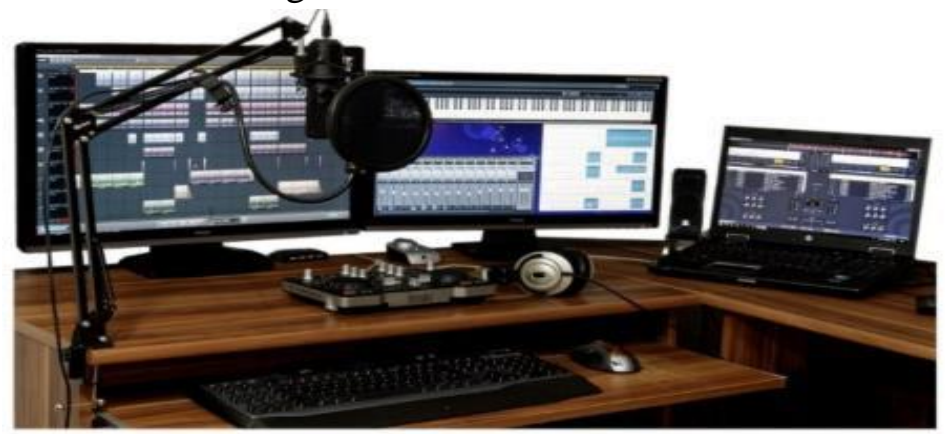

Figure 4. Recording Tool Settings

After all the tools are installed neatlv then the step taken is to open the Cubase 5 software by double clicking the Cubase 5 ( $\bullet$ ) icon on the desktop, then the process box will appear as below.

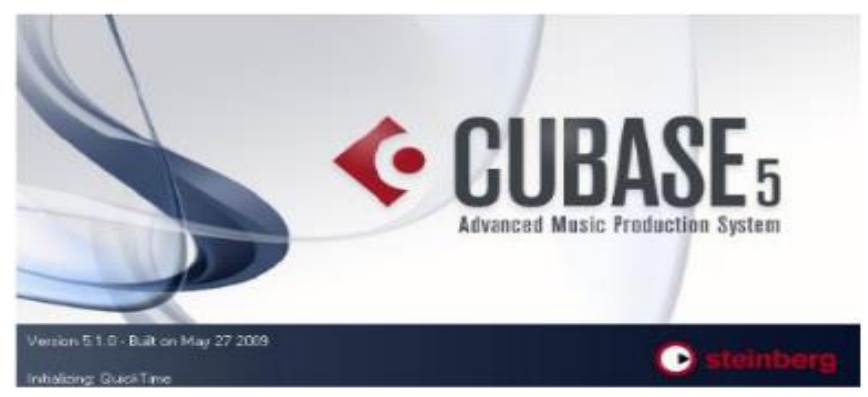

Figure 5. Initial Display Process Box of Cubase 5 
Then the "Project Assistant" dialog box will appear. Click "MORE" and select "EMPTY" and click "CREATE" to start the new project page.

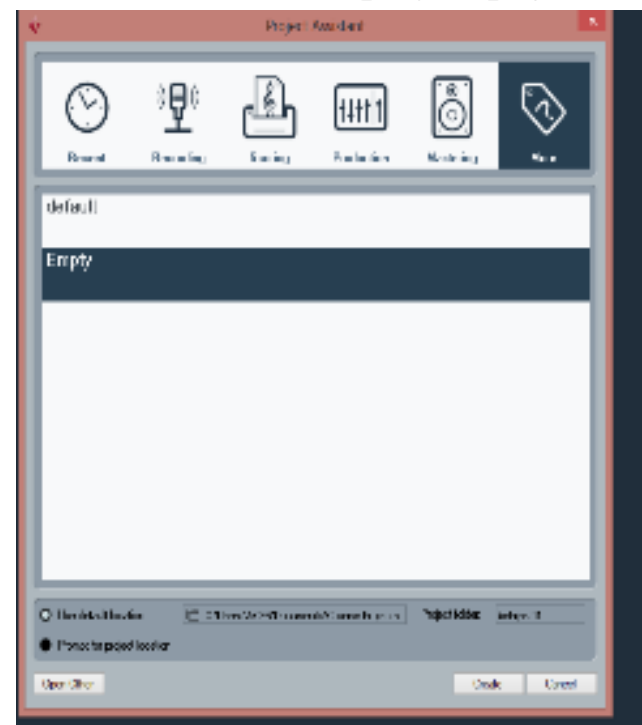

Figure 6. Dialog Box Starting a New Project Page

To ensure the project is stored in a folder, the researcher carries out the storage stage at the beginning of the process by clicking CTRL $+\mathrm{S}$ and giving the folder name "GOBUK" as the name of the folder where the digital music data is stored.

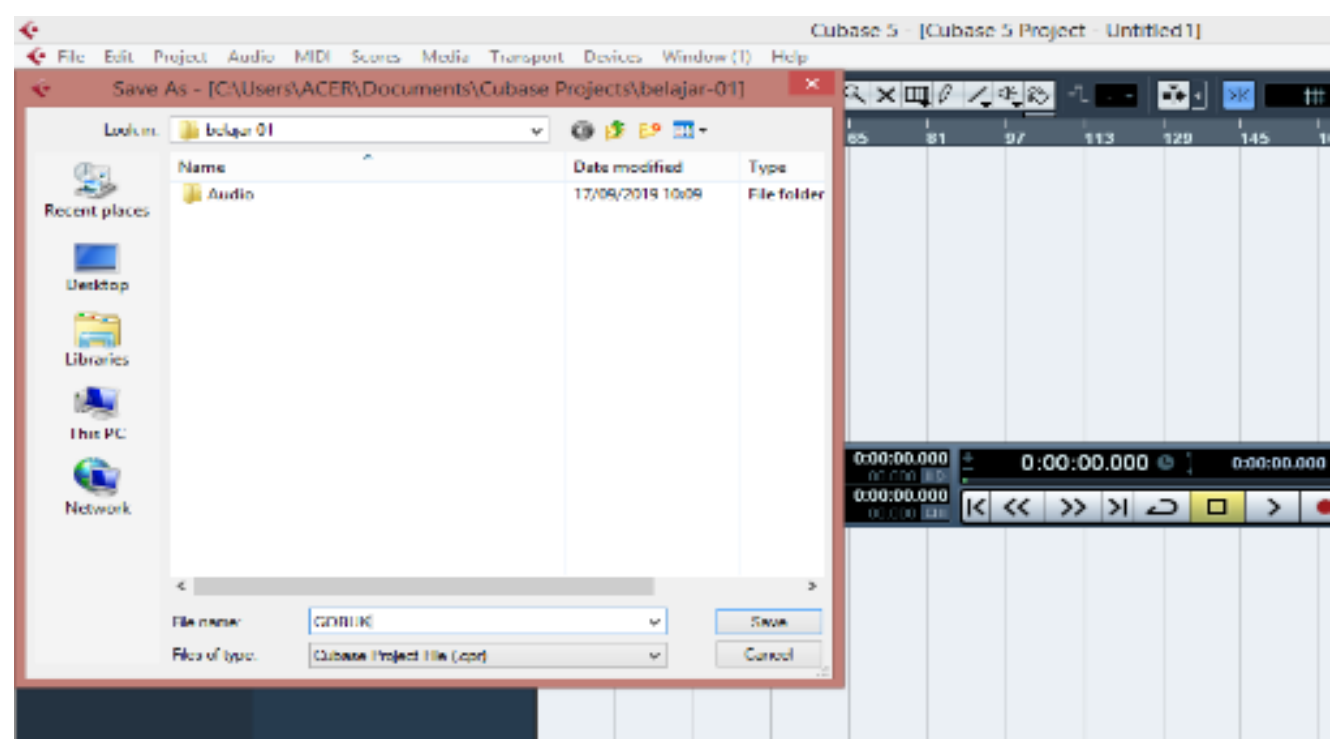

Figure 7. Save Project Dialog Box

Next the researchers conducted the recording process. There are two ways that taken in the recording process, namely recording per instrument (one track one instrument) and recording all instruments at once (one track all instrument). For the case of gobuk dance music, the second method is chosen, one track all instrument, considering that gobuk music is more found in form and sense of dynamics when played together. The microphone settings for this recording are shown in the following image: 


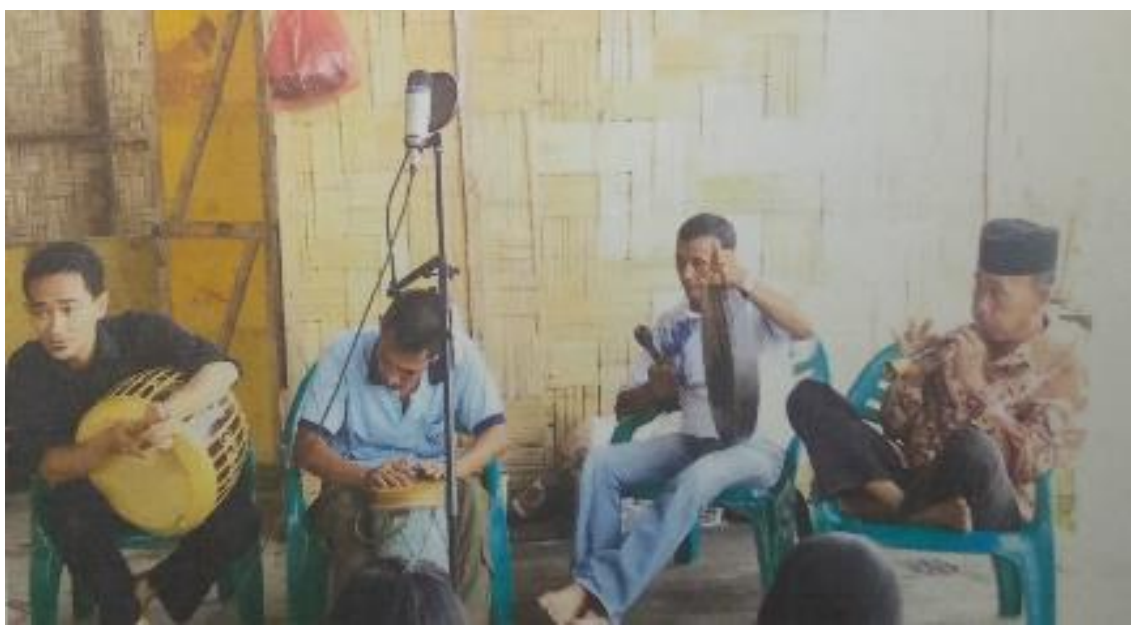

Figure 8. Microphone Settings during the Recording Process

So next is to go to the dialog box at the top then select PROJECT-ADD TRACKAUDIO as follows:

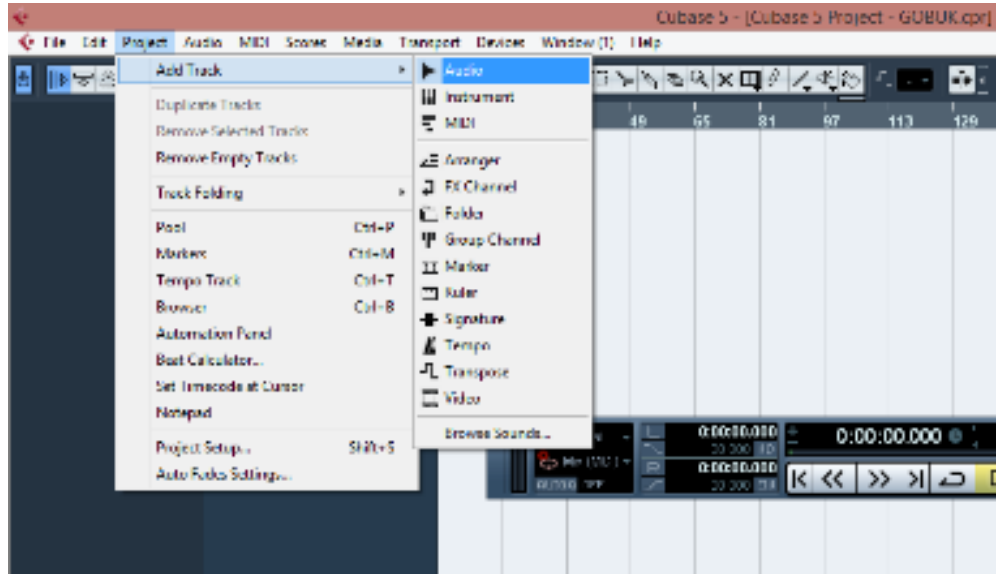

Figure 9. Adding an Audio Track

Then the following dialog box appears and click OK.

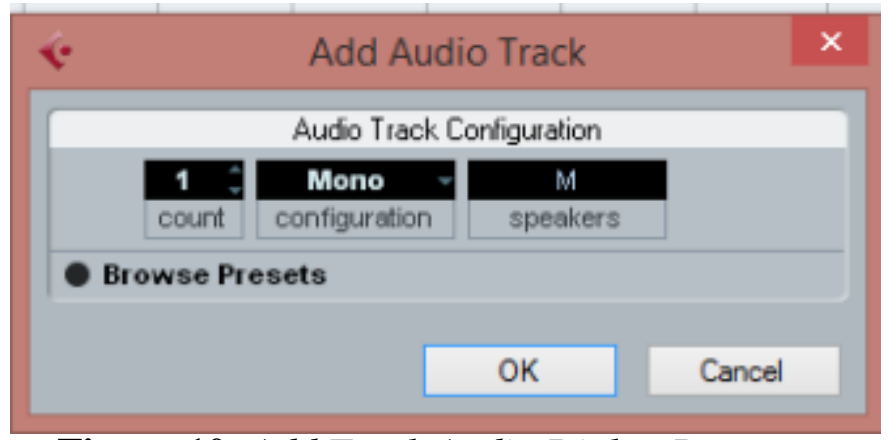

Figure 10. Add Track Audio Dialog Box

Then the audio line will appear in cubase 5. Then click the record button ( $\bullet$ ) to start the recording process. 
Budapest International Research and Critics Institute-Journal (BIRCI-Journal)

Volume 2, No 4, November 2019, Page: 556-566 e-ISSN: 2615-3076(Online), p-ISSN: 2615-1715(Print)

www.bircu-journal.com/index.php/birci emails: birci.journal@gmail.com birci.journal.org@gmail.com

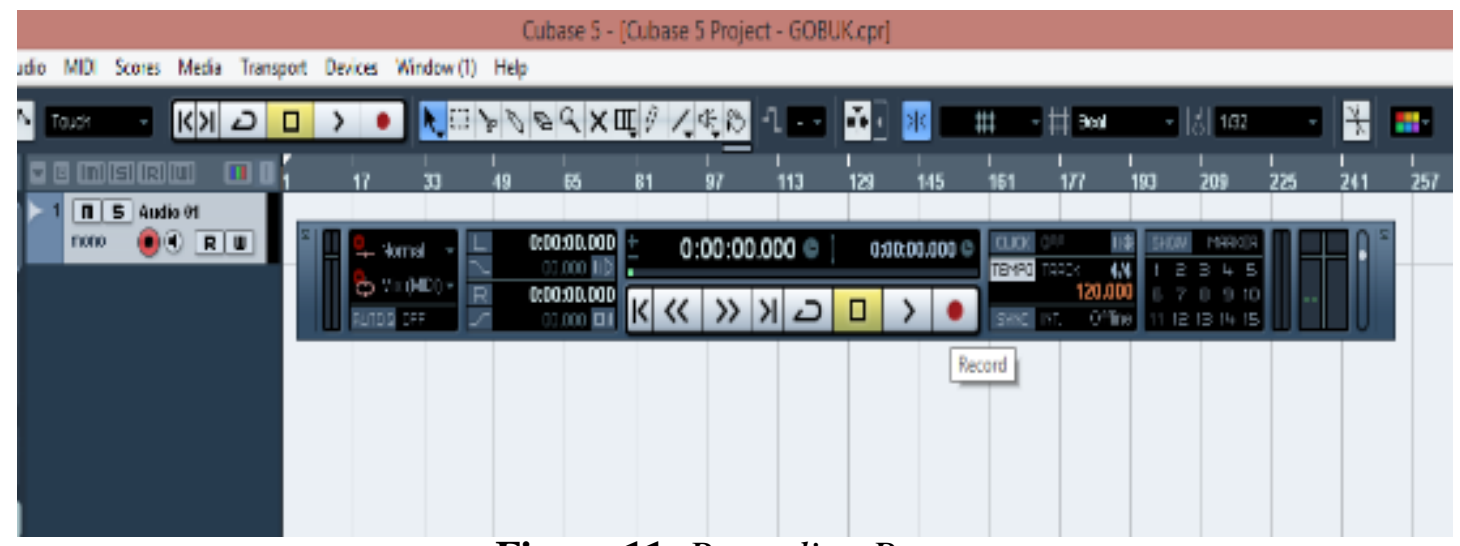

Figure 11. Recording Button

This process is carried out in 3 parts of the gobuk dance music namely Hontak Kudo, Perang (Magic), and Perang. The results of the recording of the three music sections are shown by each of the following graphs:

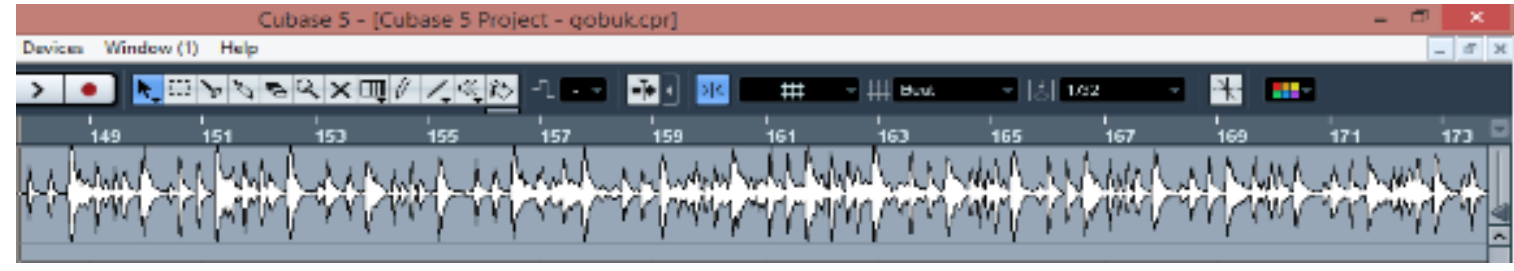

Figure 12. Graph of Hontak Kudo Audio Track

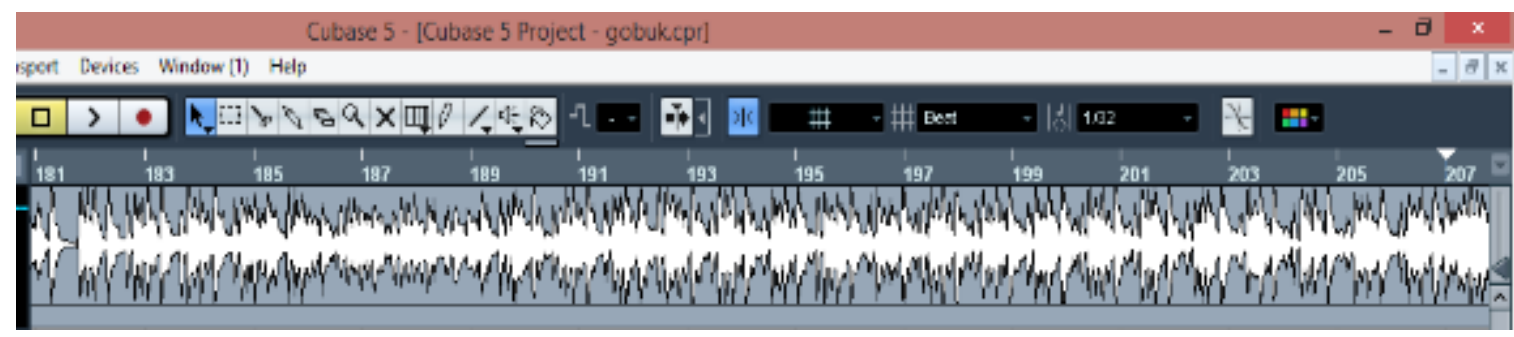

Figure 13. Graph of Magic Audio Track

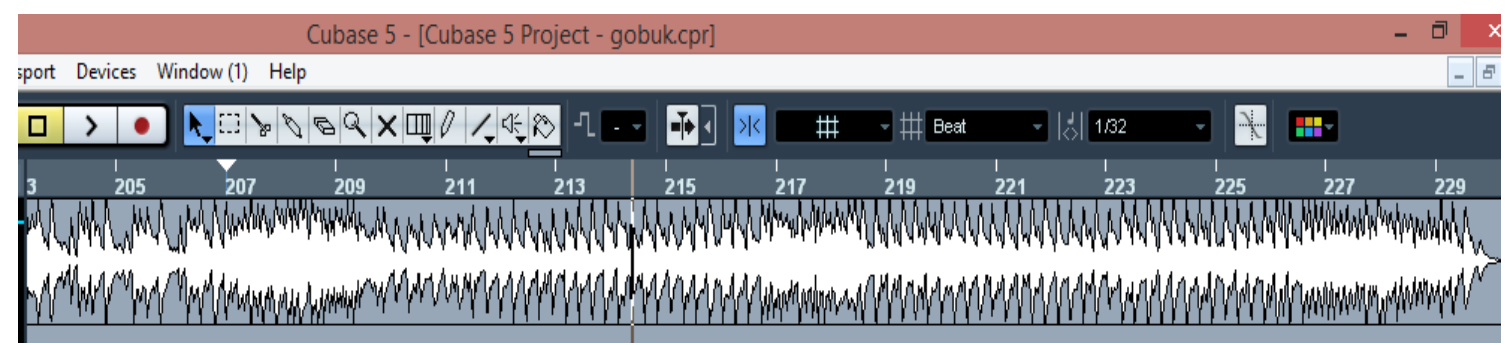

Figure 14. Graph of perang Audio Track

Note that the density and magnitude of the graph are influenced by the tempo and dynamics of the music. The closer the graph shows the faster tempo and vice versa. Then the bigger the graph shows the dynamic is getting stronger and vice versa. 
Editing stage includes the process of cutting tracks (cutting), removing parts of the tracks that are not needed, compression, adding effects such as reverb, chorus, etc., reducing noise, etc. to enhance audio quality. In summary, the use of effects on the gobuk ritual dance music can be seen in the following figure:

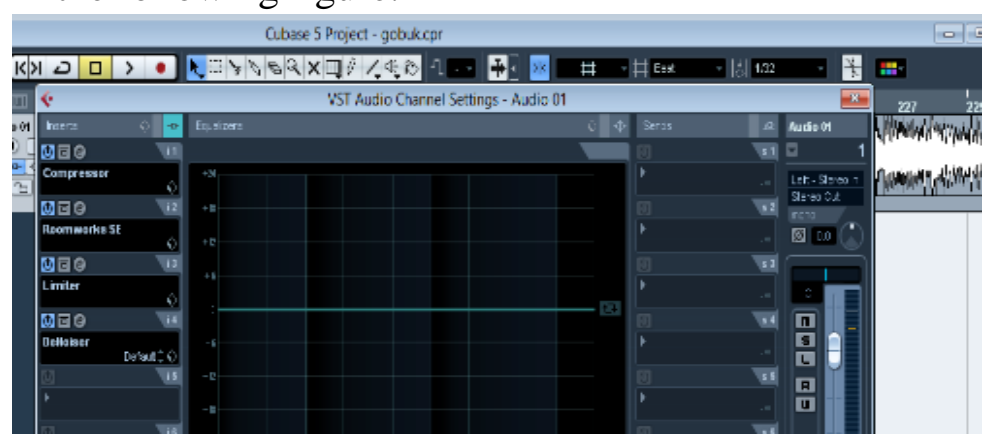

Figure 15. Adding several plug-ins in the editing process

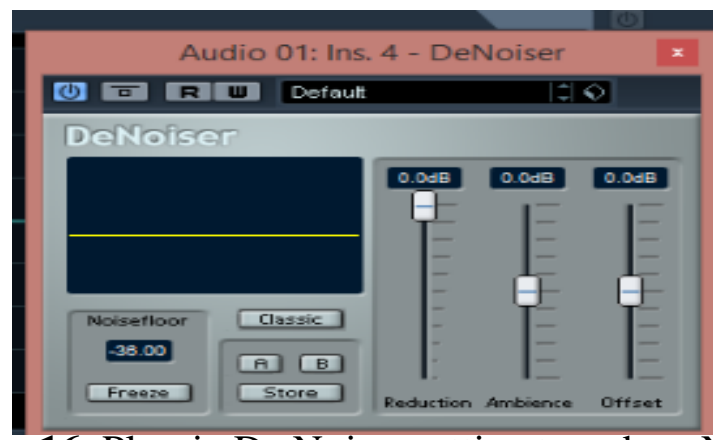

Figure 16. Plug-in De Noiser setting to reduce Noise

The digitization process ends with the Mixing and Mastering Stages, the stages used to mix all the results that have been recorded or drawn using a key editor. Frequency adjustment, equalizer settings, addition of compressors, on each track so that the recording results are more harmonious. Mastering stage is the stage where the equalizer, compressor and to increase the volume of the sound on the recording results that have passed the mixing stage first.

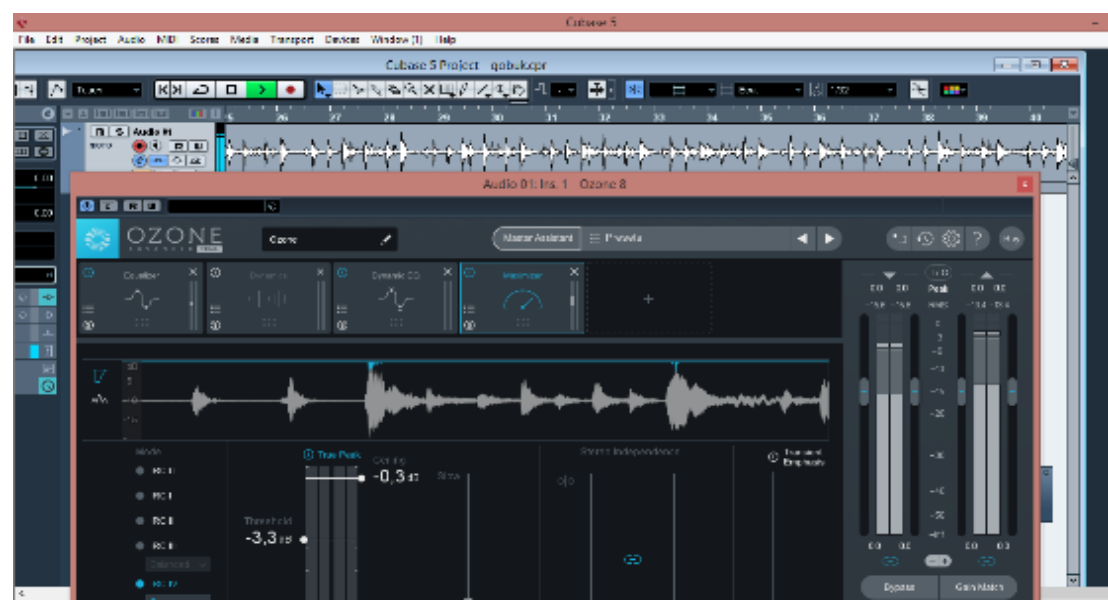

Figure 17. Process of Gobuk Music in Mixing-Mastering 


\section{Conclusion}

The use of Cubase 5 software is very effective in the digitalization of North Sumatra Malay ritual music. In addition to its use which is concise and easy to operate, its features are also very adequate for the digitization process from the recording, editing, to the mixing and mastering stages of music. The obstacle is that traditional musicians find it difficult to follow the metronome so it is difficult to do track by track recording. But this is not so an obstacle and can be dealt with by recording all instruments by one track. It is expected that this study stage can be a reference for subsequent researchers in conducting similar studies on other ritual music. Then it is hoped that the next researcher will be able to correct the stages that are less appropriate such as a better mixing and mastering process.

\section{References}

Arfah, H. (2009). Fungsi makna simbolik tari gobuk pada masyarakat melayu pesisir asahan kota tanjung balai. Skripsi Sarjana Program Studi Pendidikan Tari Universitas Negeri Medan.

Fernandus. (2017). Tari gobuk pada masyarakat melayu pesisir Asahan kota tanjung balai. Tesis Magister Penciptaan dan Pengkajian Universitas Sumatera Utara.

Hamdani, H. (2019). Pengobatan gobuk dan seni tradisi melayu pesisir tanjung balai asahan. Tesis Magister Penciptaan dan Pengkajian Universitas Sumatera Utara.

Holmes, T. (2008). Electronic and Experimental Musik and Culture. New York: Routledge.

Laksono, Y.T. (2018). Teknologi pengembangan digital dalam mengembangkan komposisi dan aransemen pada musik menggunakan software cubase. VIRTUOSO (Jurnal Pengkajian Dan Penciptaan Musik), 1 (1): pp. 30-33.

Permadi. T.A. \& Budiwati. D.S. (2017). Implikasi penggunaan media audio digital terhadap pembelajaran gamelan degung di departemen pendidikan seni musik fpsd upi . Jurnal Pendidikan UPI. 1-10.

Roger. S. P. (2012). Rekayasa Perangkat Lunak Pendekatan Praktisi. Yogyakarta: Andi.

Samino. S.R.I. (2017). Penerapan Media Software Cubase Dalam Pembuatan Aransemen Musik. Jurnal IMEDTECH, 1 (2), 44-59. 